\title{
超臨界水を用いたアスファルト抽出試験 に関する基礎検討
}

\author{
加納陽輔 ${ }^{1} \cdot$ 秋葉正一 $^{2} \cdot$ 栗谷川裕造 $^{3} \cdot$ 河合糺茲 4 \\ 1 学生員工修 日本大学大学院 生産工学研究科土木工学専攻 （テ275-8575 千葉県習志野市泉町 1-2-1） \\ ${ }^{2}$ 正会員 工博 日本大学 生産工学部土木工学科（广275-8575 千葉県習志野市泉町 1-2-1） \\ ${ }^{3}$ 正会員 工博 日本大学教授 生産工学部土木工学科（广275-8575 千葉県習志野市泉町 1-2-1） \\ ${ }^{4}$ フェロー会員 工博 日本大学教授 生産工学部土木工学科（T275-8575 千葉県習志野市泉町 1-2-1）
}

\begin{abstract}
従来，アスファルトの抽出・回収試験には三塩化エタンが多く使用されてきたが，人体や環境に対する安 全性への配慮から，1995 年をもって全廃止されることとなった. このため, 各機関では植物系または石油系 の代替溶剤が選定され，近年では自動化の装置も実用されている.しかしながら，これらの代替方法につい ては, 乾燥方法や廃液処理方法, 改質アスファルトへの適用等, 未だ多くの課題を残している. 本研究では, 安全性・簡便性・経済性の向上をはじめ, 所要時間の短縮や改質アスファルトへの適用を目標に, 超臨界水 を用いた抽出試験に関する基礎的検討を試みた。この結果, 超臨界水の優れた抽出性能と高精度の骨材回収 能力が認められ，抽出試験としての適応性を示唆する成果が得られたのでこれを報告する.
\end{abstract}

Key Words : Supercritical Water, Extraction Asphalt, Aggregate, Straight Asphalt, Modified Asphalt

\section{1. はじめに}

表層・基層に用いるアスファルト混合物や上層路盤等 に用いるアスファルト安定処理混合物については，新材 あるいは再生材を問わず，その品質および出来形規格值 として，アスファルト含有量と骨材合成粒度の規格值が 設けられている ${ }^{1)}$. このため, アスファルト混合所なら びに再生アスファルト混合所においては, アスファルト 混合物や再生骨材の品質管理を目的としたアスファルト 抽出試験（以下, 抽出試験）の実施が, 重要な管理項目 として位置づけられている ${ }^{2)}$.

抽出試験方法には，主に減圧式ソックスレー抽出法, 自動遠心分離抽山法, 強制循環式自動抽出法, 常圧式y ックスレー抽出法等があるが, 各機関によって使用して いる溶剤および装置は異なっている ${ }^{3)}$.しかしながら, 抽出試験においてはいずれも, 品質管理として配合を直 接確認し，管理データとして重要な意味を有することか ら, 所要の試験精度はもとより, その安全性や簡便性が 要求される.

アスファルトの抽出・回収用溶剂については, 従来, その溶解性と難然性等から 1.1.1トリクロロエタン(以下, 三塩化エタン）が多く使用されてきた。しかしながら， 人体や環境に対する安全性への配慮から, 1995 年 12 月以 降，エッセンシャルユースを除き全廃止されている ${ }^{4)}$.
これを受けて，各機関では代替溶剤や試験方法・装置 の検討が急務となり，毒性または引火性を考慮した植物 系, 石油系等の溶剤が選定されることとなった.さらに, 近年では自動化のものも開発され，試用および実用され

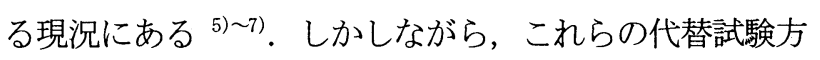
法に関しては，三塩化エタンと同等の結果が得られてい るものの, 溶剤コストや廃液処理方法, 乾燥方法をはじ め, 累増傾向にある改質アスファルトへの適用等, 代替 溶剂の性状に起因する幾つかの課題を残している ${ }^{2)}$.

本研究では, 新たな分離・抽出溶媒として注目されて いる ${ }^{8), 9)}$ 超臨界水の溶媒性能に着目し, 改質アスファルト へひ適応や所要時間の短縮, 簡便性およひ経済性, 人体 や環境に対する安全性の向上等を目標に，アスファルト 抽出試験への適用を試みた。この結果, 超臨界水の優れ た抽出性能と, 高精度の骨材回収能力が認められ, 抽出 試験としての適用性を示唆する成果が得られたのでこれ を報告する。

\section{2. アスファルト抽出溶媒としての超臨界水}

近年, 抽出試験に用いられる溶剤は, 引火性のものか ら不然性のもの一，さらにより毒性の低いものへと移行 してきた. 代表的な塩素系, 植物系, 石油系抽出溶剂の 性状を表 - 1 に示す. 
表 - 1 抽出溶剤の性状

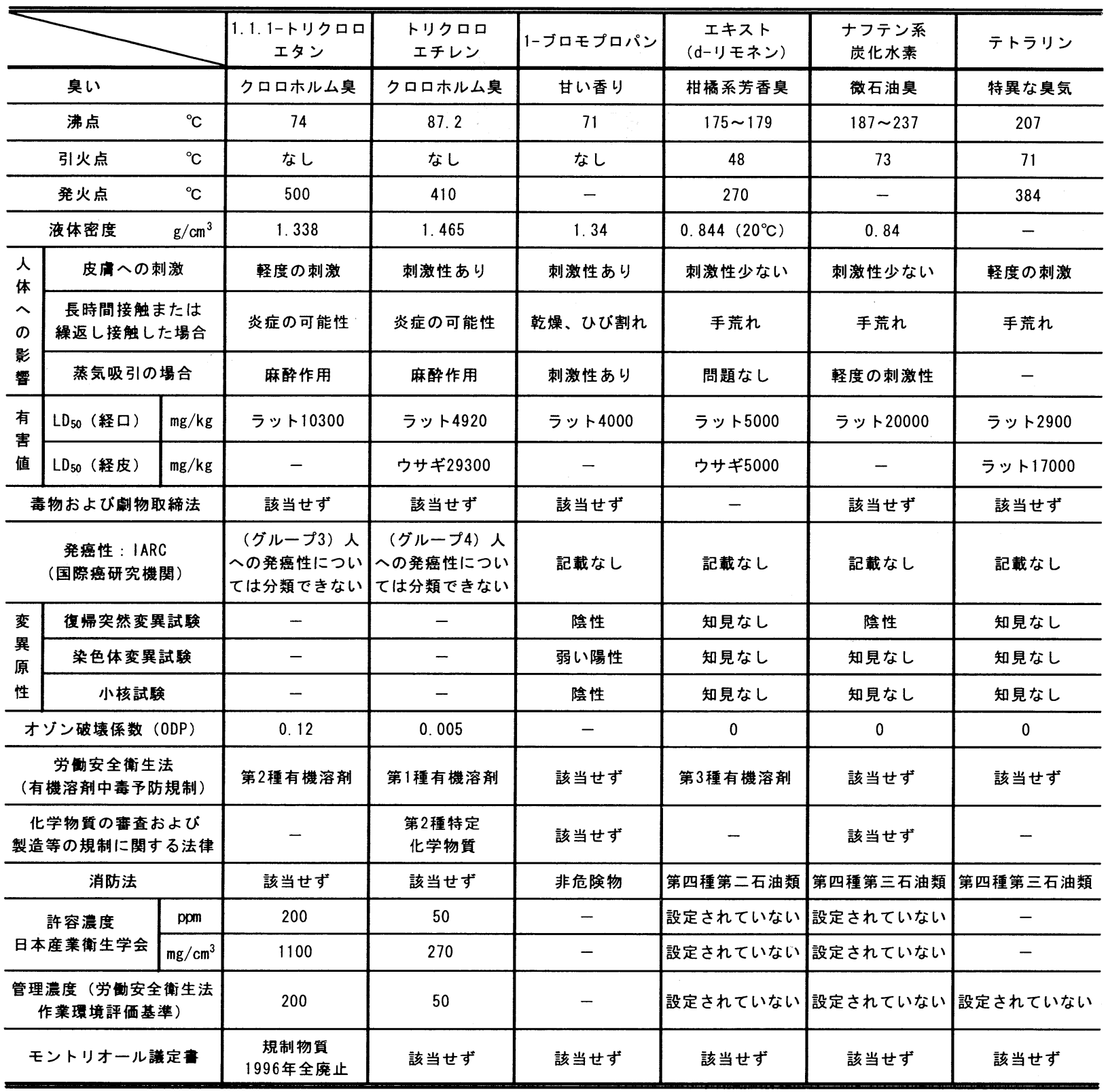

1・ブロモプロパンは, 沸点, 引火点ともに三塩化エタ ン（表中：1.1.1トリクロロエタン）と同程度であるもの の，毒物および劇物取締法，労働安全衛生法，オゾン層 破壊物質には該当していない，また，エキスト，ナフテ ン系炭化水素，テトラリンは，毒性や発癌性，オゾン層 破壊等の安全性に配慮した溶剤と言えるが，三塩化エ夕 ンに比べて沸点が高く，引火性を有している.

このように，アスファルトの抽出・回収用溶剂はいず れにせよ，毒性あるいは危険性が全くないとは言い難く， 溶解性や引火性等を比較しても，各々は一長一短である と言える.このことからも，各溶剤の取り扱いにあたっ ては，今後も関連法規を遵守寸るとともに，溶剤の性質 に関する教育や，明確な表示を徹底させることが必要と なる.
以上を踏まえ，本研究で検討する抽出試験では，純水 を抽出溶媒として使用寸るため，毒性や危険性，引火性 はもとより, 溶剤コストや廃液処理, 乾燥方法等の課題 に関しても十分な対処が可能であると考えられる.

また，超臨界流体は，臨界温度と臨界圧力を超えた非 凝縮性流体であり，その密度は温度や圧力を僅かに変え ることで，気体から液体程度まで連続的かつ大幅に変化 する. このため, 密度の関数として表せる多くの溶媒物 性や輸送物性を精密に制御し，目的に応じた溶媒性能を 付与することが可能となる. 中でも, 水は最も多様な物 質を溶かすことのできる液体であり，人体や環境に対す る安全性と経済性の確保，入手が容易であることを考慮 して, 本研究では臨界温度を基準とした高温・高圧水に 着目し，抽出試験への適用に向けた基礎的検討を試みた. 

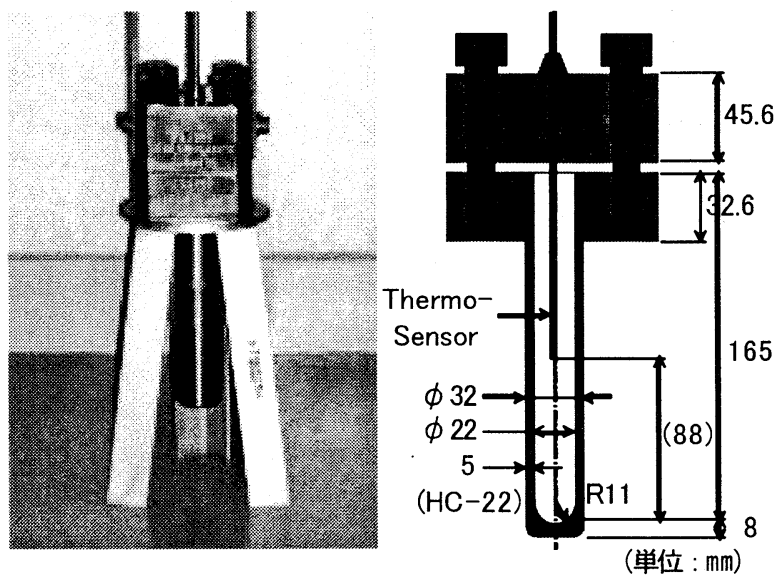

図 - 1 超臨界熱反応用密閉容器

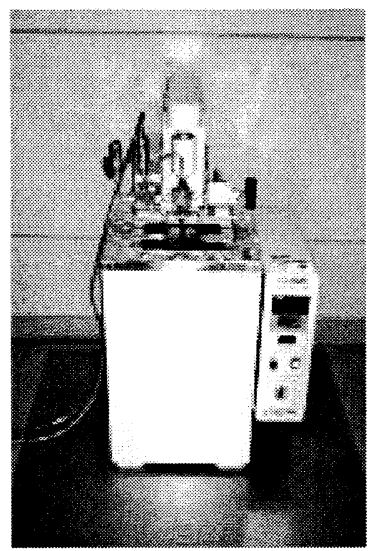

\begin{tabular}{|c|c|}
\hline 外形寸法 & $\begin{array}{l}\text { W550 × D550 X } \mathrm{H} 850 \mathrm{~mm} \\
\text { (液楮部590+樭拌部 } 260 \mathrm{~mm} \text { ) }\end{array}$ \\
\hline 槽内寸法 & $\mathrm{W} 200 \times \mathrm{D} 200 \times \mathrm{H} 450 \mathrm{~mm}$ \\
\hline 温度範囲 & $+300 \sim+600^{\circ} \mathrm{C}$ \\
\hline 温度安定度 & $\pm 0.5^{\circ} \mathrm{C}$ \\
\hline 温度調節 & $\begin{array}{c}\text { テジタル式温度指示調節器 } \\
\text { PID制御方式 }\end{array}$ \\
\hline 七-タ- & シースワイヤー式 $4 k W$ \\
\hline 擋拌機 & $\begin{array}{c}\text { 維型擋拌方式 } \\
\text { スピードコントロールモータ } \\
\text { 100W (タイマー付き) }\end{array}$ \\
\hline 定格電源 & $A C 200 \mathrm{~V}$ 単相 $50 / 60 \mathrm{~Hz}$ \\
\hline 定格 & $21 \mathrm{~A}$ \\
\hline 重量 & $\begin{array}{l}\text { 約 } 81 \mathrm{~kg} \\
\end{array}$ \\
\hline
\end{tabular}

図 - 2 超臨界試験用加熱槽

以下に，超臨界水の溶媒特性と抽出試験への適用性を 示唆する科学的根拠について述べる.

液体の水は, 通常 $100^{\circ} \mathrm{C}$ で沸騰し気体となるが, 密閉容 器内で加熱することによって, 沸点および圧力は上昇し 続け，臨界温度 $\left(374.2^{\circ} \mathrm{C}\right)$ と臨界圧力（22.1MPa）を越 えると「超臨界水」となり，気体と液体の区別がなくな る. また，流体物質の基本的な性状は主にその密度で決 まるが, 超臨界状態では圧力上昇に伴う密度の増加によ って, 液体同様に溶解力が向上し, 高温下における激し い分子運動から気体に匹敵する拡散速度と粘性が得られ る.

このように，超臨界水は温度または圧力操作による密 度の増減をはじめ, イオン積や誘電率等の性状変化から, 通常の水では分離してしまう無極性の有機物を溶解する ことが可能となる.

以上から，純水は人体や環境への負荷が極めて小さい 溶媒であることを前提に, 超臨界水のアスファルト抽出 性能および骨材回収能力が期待される.

\section{3. 高温 - 高圧水反応試験}

本研究では，超臨界水を用いた抽出試験に関する基礎
表 - 2 温度・圧力レベルにおける仕込水量

\begin{tabular}{c|c|c|c|c}
\hline & $30 \mathrm{MPa}$ & $35 \mathrm{MPa}$ & $40 \mathrm{MPa}$ & $45 \mathrm{MPa}$ \\
\hline $300^{\circ} \mathrm{C}$ & 51.54 & 51.78 & 52.15 & 53.14 \\
$325^{\circ} \mathrm{C}$ & 48.50 & 48.92 & 49.46 & 49.92 \\
$350^{\circ} \mathrm{C}$ & 44.73 & 45.69 & 46.64 & 46.87 \\
$375^{\circ} \mathrm{C}$ & 39.78 & 41.62 & 42.10 & 43.42 \\
$400^{\circ} \mathrm{C}$ & 27.62 & 34.83 & 37.12 & 38.93 \\
$425^{\circ} \mathrm{C}$ & 17.30 & 24.76 & 30.65 & 32.03 \\
$450^{\circ} \mathrm{C}$ & 13.98 & 17.39 & 20.05 & 27.57 \\
\hline \hline
\end{tabular}

検討として, 反応時間, 温度・圧力レベルとアスファル 卜抽出性能との関係を究明し, 微細骨材分に対する骨材 回収能力について検討を行った.

反応試験および試料回収の手順を以下に述べる.

(1) 高温・高圧水反応試験は, 図 - 1 に示寸超臨界熱反応 用密閉容器（TSC-006 型反応容器 : 内容積 $60 \mathrm{cc}$ ）（以 下，セル）に，目標とする圧力が得られるよう水蒸 気圧をもとに算出した仕込量の水（表 - 2 参照）およ び供試体を投入する.

(2) セルを試験温度に設定した図 - 2 の超臨界試験用加 熱槽（TSC-600 型超臨界試験用硝石槽）（以下，ソル トバス）に沈めて静置し，加熱および反応を行う.

(3) 反応時間が経過後, セルを開封して内容物（骨材分 および溶媒）を回収し，濾過（ガラス繊維濾紙 : 粒 子保持能 $1.6 \mu \mathrm{m}$ ) を行う. なお, 分離されたアスフ アルト分は, 溶媒水面に油膜状となって存在するた め, これを十分に除去した後, 純水を用いて内容物 を丁寧に濯ぎ出す.

(4) 濾過が完了した後, 濾過残留分を質量が一定となる まで炉乾燥 $\left(110^{\circ} \mathrm{C}\right)$ させ，デシケータ内で室温まで 放冷して反応後質量 $\left(\mathrm{M}_{\mathrm{r}}\right)$ を $1.0 \times 10^{-4} \mathrm{~g}$ まで計量す る. なお, 反応条件によってアスファルトの分離が 不十分であった場合, 特に微細粒分供試体について は，その一部が濾紙表面に付着し，正確な試料の回 収および計量が行えない，このため，濾紙表面をへ キサンによって洗浄し，これを濾紙残留物と合わせ て炉乾燥した。

\section{4. 反応時間と抽出性能の関係}

高温・高圧水のアスファルト抽出溶媒としての適性を 評価する上で，抽出時間の究明が必要不可欠である. 本 項では，粗骨材供試体に対する反応試験から，反応時間 と抽出性能の関係について検討した.

バインダーは，一般的な舗装に多く使用されているス トレートアスファルト 60-80（以下，St.As.）を用いた. St.As.の性状を表 - 3 に示す. 
表 - 3 使用アスファルトの性状

\begin{tabular}{|c|c|c|c|c|}
\hline \multicolumn{3}{|c|}{ 試釦項目 } & $\begin{array}{c}\text { ストレーアスファル } \\
60 / 80\end{array}$ & 改筫 II型アスファルト \\
\hline \multicolumn{2}{|c|}{ 針入度 $\left(25^{\circ} \mathrm{C}\right)$} & $1 / 10 \mathrm{~mm}$ & 62 & 52 \\
\hline \multicolumn{2}{|c|}{ 軟化点 } & ${ }^{\circ} \mathrm{C}$ & 49.0 & 61.5 \\
\hline \multicolumn{2}{|c|}{ 伸度 } & $\mathrm{cm}$ & $150+$ & 60 \\
\hline \multicolumn{2}{|c|}{ 引火点 } & ${ }^{\circ} \mathrm{C}$ & 362 & 305 \\
\hline \multicolumn{2}{|c|}{ 薄膜加熱針入度残留率 } & $\%$ & 64.0 & 80.8 \\
\hline \multicolumn{2}{|c|}{ タフネス ( $\left.25^{\circ} \mathrm{C}\right)$} & $\mathrm{N} \cdot \mathrm{m}$ & - & 18.4 \\
\hline \multicolumn{2}{|c|}{ テナシティ ( $\left.25^{\circ} \mathrm{C}\right)$} & $\mathrm{N} \cdot \mathrm{m}$ & - & 14.1 \\
\hline \multicolumn{2}{|c|}{ 密度 $\left(15^{\circ} \mathrm{C}\right)$} & $\mathrm{g} / \mathrm{cm}^{3}$ & 1.041 & 1.030 \\
\hline \multirow{3}{*}{ 動粘度 } & $\left(140^{\circ} \mathrm{C}\right)$ & $\mathrm{mm}^{2} / \mathrm{s}$ & 904 & 767 \\
\hline & $\left(160^{\circ} \mathrm{C}\right)$ & $\mathrm{mm}^{2} / \mathrm{s}$ & 210 & 323 \\
\hline & $\left(180^{\circ} \mathrm{C}\right)$ & $\mathrm{mm}^{2} / \mathrm{s}$ & 69 & 172 \\
\hline
\end{tabular}

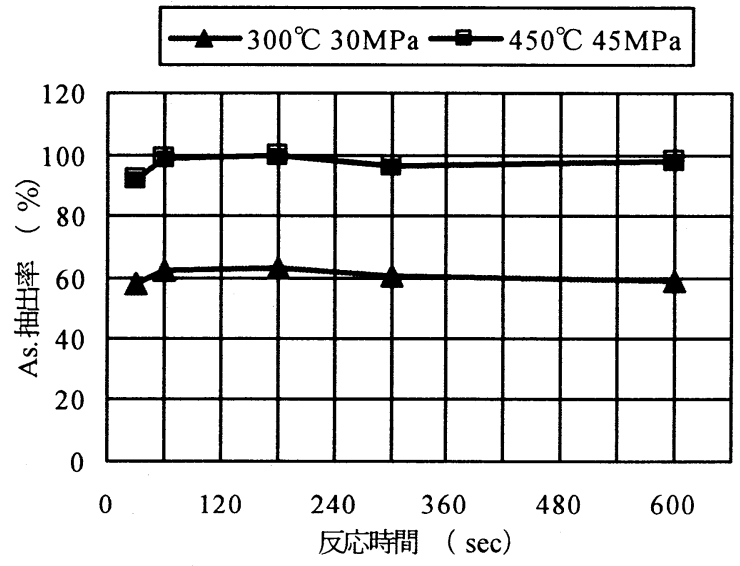

図 - 3 As.抽出率と反忘時間の関係

供試体は, 粗骨材 (6 号砕石 : 杤木県産硬質砂岩, 粒径 4.75 13 mm) 単体に, アスファルトを被膜・含浸させて 作製し，同程度のアスファルト量が得られた試料を反応 試験に供した。

粗骨材供試体の作製および計量手順を以下に示す。

(1) 供試体個体差の影響を軽減させるため, 6 号砕石中か ら形状が類似した $2.7 \pm 0.3 \mathrm{~g}$ 程度の試料を選別する。

(2) 選別した試料を質量が一定となるまで炉乾燥 $\left(110^{\circ} \mathrm{C}\right)$ させ，デシケータ内で室温まで放冷して被 膜前質量 $\left(\mathrm{M}_{\mathrm{a}}\right)$ を $1.0 \times 10^{4} \mathrm{~g}$ まで計量する.

(3) 計量後の試料をアスファルトの混合温度まで加熱し た後，同温度に保ったアスファルト中へ $180 \mathrm{sec}$ 程度 没する.

(4) アスファルト中から試料を取り出し, 密閉容器内で 適度に摚拌して，アスファルトの偏在または余分な ダレを取り除く.

(5) 被膜後の試料をデシケータ内で静置・放冷し，(2)同 様に被膜後質量（ $\left.\mathrm{M}_{\mathrm{f}}\right)$ を計量する，なお，(2)，(5)の 質量差から被膜したアスファルトの質量を求め, ア
スファルト量が 1.7〜 2.0wt\%程度（内掛）となったものを 供試体として用いた.

反応条件に関しては, 温度 $300 \sim 450^{\circ} \mathrm{C}$, 圧力 $30 \sim 45 \mathrm{MPa}$ を本研究範囲に想定したため, 最低または最高条件とな る $300^{\circ} \mathrm{C} ・ 30 \mathrm{MPa}$ および $450^{\circ} \mathrm{C} ・ 45 \mathrm{MPa}$ にて基礎実験を 試みた。なお，反応時間は，試験条件とする各温度，圧 力に到達後，30，60，180，300，600secの 5 通りにて実 施した。

試験結果は，被膜・ 反応前後の供試体質量変化から式 （1）を用いてアスファルト抽出率（以下，As.抽出率） を算出し, 各試験条件下 3 回の平均 As.抽出率を求めて反 応時間と抽出性能の関係について比較検討した。

$$
R_{A}=\frac{M_{f}-M_{r}}{M_{f}-M_{a}} \times 100
$$

$$
\begin{aligned}
& R_{A}: \text { As.抽出率 }(\%) \\
& M_{a}: \text { 被膜前質量 }(\mathrm{g}) \\
& M_{f}: \text { 被膜後質量 }(\mathrm{g}) \\
& M_{r}: \text { 反応後質量 }(\mathrm{g})
\end{aligned}
$$

As.抽出率と反応時間の関係を図 - 3 に示す.

高温・高圧水のアスファルト抽出性能は, 反応条件 $300^{\circ} \mathrm{C} \cdot 30 \mathrm{MPa}$ と $450^{\circ} \mathrm{C} \cdot 45 \mathrm{MPa}$ で大きな差異が生じたも のの, 双方とも反応時間 $60 \mathrm{sec}$ 以降でAs.抽出率の変化は 見られず，ほぼ一定の值となった。

このことから，反応時間と抽出性能の関係については, 一定の時間で抽出作用が完了寸るものと考えられ， $450^{\circ} \mathrm{C} \cdot 45 \mathrm{MPa}$ においては, 僅か $60 \mathrm{sec}$ の反応でほぼ 100\% のAs.抽出率が得られた.

\section{5. 温度・圧カレベルと抽出性能の関係}

温度および圧力の異なる高温・高圧水反応試験から， 各反応条件下におけるアスファルト量の推定精度を評価 し, 抽出試験としての適性と温度・圧力レベルが抽出性 能に与える影響について検討した.

供試体は，反応条件と抽出性能の関係をより明確にす るため，骨材損失等の誤差が少ない粗骨材を用いて作製 した. バインダーは，前項と同様のSt.As，および骨材把 握力が強く，耐流動，䘏摩耗等を目的に用いられる改質 II型アスファルト (以下，Mod.IIAs.) の 2 種類を使用し た。供試体の作製および計量手順については，前項と同 様である. St.As.ならびに Mod.II As.の性状を表 - 3, 各温 度・圧力レベルにおける仕込水量を表 - 2 に示寸.

反応試験は，温度を $300 ， 325 ， 350 ， 375 ， 400 ， 425$, $450^{\circ} \mathrm{C}$ の 7 通りに対して, 圧力を $30 ， 35 ， 40 ， 45 \mathrm{MPa}$ の 計 28 条件で実施した。 また，反応時間は各条件下におけ る抽出性能が十分に評価できるよう，前項の検討結果を 


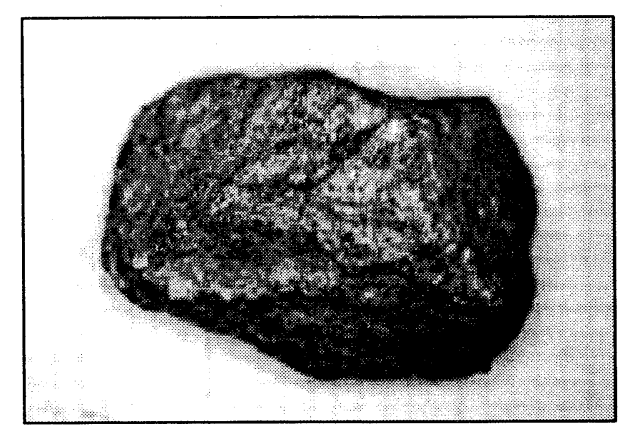

a）被膜前

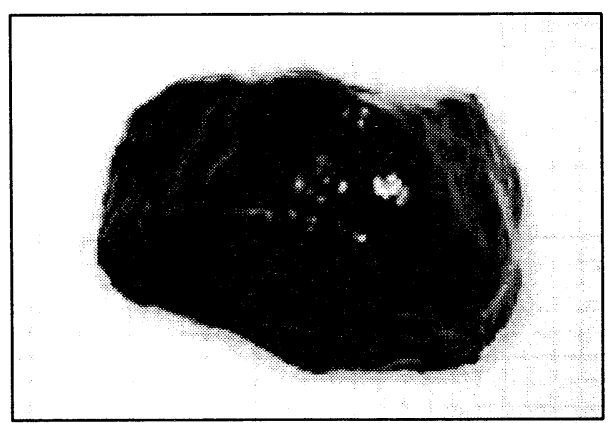

b) 被膜後

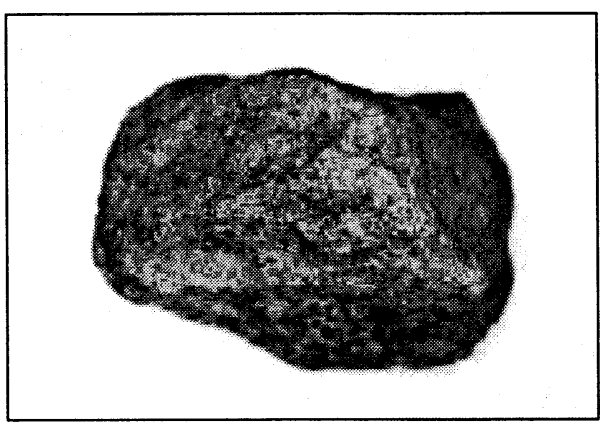

c） 反応後

図 - 4 供試体表面の変化（Mod. II As. ・粗骨材） 反応条件 : $400^{\circ} \mathrm{C} \cdot 40 \mathrm{MPa}$, 反応時間 : $180 \mathrm{sec}$

踏まえて $180 \mathrm{sec}$ とした.

試験結果は, 反応前後の供試体質量変化より式 (2) を 用いて推定アスフォルト量 (以下, 推定 As.量) を算出し, 供試体作製時におけるアスファルト量との質量差から温 度・圧力レベルと抽出性能の関係につて検討を行った.

$$
A C=\frac{M_{f}-M_{r}}{M_{f}} \times 100
$$

$$
\begin{array}{r}
A C: \text { 推定 As. 量 }(\%) \\
M_{f}: \text { 被膜後質量 }(\mathrm{g}) \\
M_{r}: \text { 反応後質量 }(\mathrm{g})
\end{array}
$$

図 - 4 は，上段から Mod.II As.被膜前，被膜後，超臨界 水反応後の供試体表面を撮影した一例である.
表 - 4 反応条件と推定 As.量誤差の関係（St.As）

\begin{tabular}{c|c|c|c|c}
\hline \hline & $30 \mathrm{MPa}$ & $35 \mathrm{MPa}$ & $40 \mathrm{MPa}$ & $45 \mathrm{MPa}$ \\
\hline $300^{\circ} \mathrm{C}$ & -0.44 & -0.46 & -0.64 & -0.59 \\
$325^{\circ} \mathrm{C}$ & -0.29 & -0.32 & -0.32 & -0.18 \\
$350^{\circ} \mathrm{C}$ & -0.12 & -0.08 & -0.06 & -0.03 \\
$375^{\circ} \mathrm{C}$ & -0.06 & -0.03 & -0.06 & -0.03 \\
$400^{\circ} \mathrm{C}$ & -0.04 & -0.04 & -0.03 & -0.11 \\
$425^{\circ} \mathrm{C}$ & -0.13 & -0.07 & -0.05 & -0.07 \\
$450^{\circ} \mathrm{C}$ & -0.16 & -0.13 & -0.03 & -0.10 \\
\hline \hline
\end{tabular}

表 - 5 反応条件と推定 As.量誤差の関係（Mod. II As.）

\begin{tabular}{c|c|c|c|c}
\hline & $30 \mathrm{MPa}$ & $35 \mathrm{MPa}$ & $40 \mathrm{MPa}$ & $45 \mathrm{MPa}$ \\
\hline $300^{\circ} \mathrm{C}$ & -0.33 & -0.28 & -0.33 & -0.30 \\
$325^{\circ} \mathrm{C}$ & -0.19 & -0.14 & -0.14 & -0.17 \\
$350^{\circ} \mathrm{C}$ & -0.04 & -0.05 & -0.04 & -0.02 \\
$375^{\circ} \mathrm{C}$ & -0.04 & -0.01 & -0.06 & -0.05 \\
$400^{\circ} \mathrm{C}$ & -0.03 & -0.02 & -0.04 & -0.08 \\
$425^{\circ} \mathrm{C}$ & -0.04 & -0.02 & -0.03 & -0.07 \\
$450^{\circ} \mathrm{C}$ & -0.23 & -0.06 & -0.02 & -0.04 \\
\hline \hline
\end{tabular}

写真から確認されるとおり，既往の抽出試験において 完全に抽出しきれない可能性のある ${ }^{7), 8)}$ Mod.II As.につい ても, 超臨界水反応後 (図 - 4c) では, 被膜前の試料 (図 - 4 a) と判別できない程, 僅か $180 \mathrm{sec}$ の反応時間でアス ファルト被膜が十分に分離・除去されている.

反応条件と推定As.量誤差の関係として, 表 - 4 にSt.As, 表 - 5 に Mod. II As.被膜供試体の結果を示寸.

推定 As.量誤差と温度レベルの関係は, St.As.および Mod.II As.とも臨界温度 $\left(375^{\circ} \mathrm{C}\right)$ 付近を境に推定精度が 向上する傾向が確認された. また，推定 As.量誤差と圧力 レベルの関倸についても, St.As., Mod.IIAs.ともに反応 条件 $450^{\circ} \mathrm{C} \cdot 30 \mathrm{MPa}$ を除く条件下においては, 取分け大 きな差異は誌められなかった。 なお, 試験条件のうちで 最も高温であるにもかかわらず，推定精度が比較的低い 值となった $450^{\circ} \mathrm{C} \cdot 30 \mathrm{MPa}$ については, 反応溶媒となる 仕込水量が反応条件中で最も少ないため, 溶解力不足に なったことがひとつの原因として考えられる.

以上のことから, 温度・圧カレベルと抽出性能の関係 につては, 特に超臨界領域でその性能が顕著に発現し, $450^{\circ} \mathrm{C} \cdot 30 \mathrm{MPa}$ を除く反応条件下においては, St.Asが-0.03 $\sim-0.13 \%$, Mod.II As.が-0.01〜-0.08\% と高精度の推定 As. 量が確認された。また，これらの結果は，St.Asおよび Mod.II As.に対する超臨界水の優れた抽出性能を明示し, 超臨界水を用いた抽出試験の適用性を示唆していると言 える. 


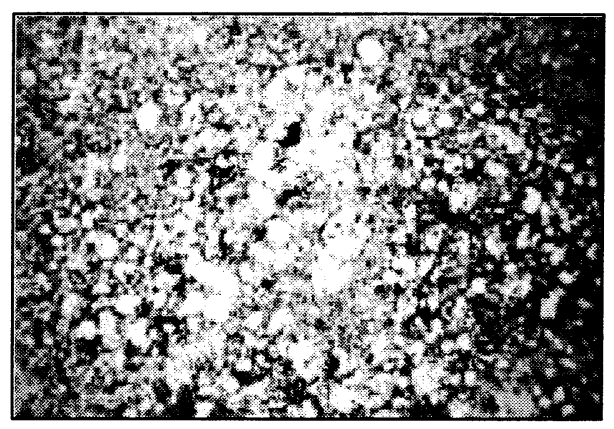

a) 混合前

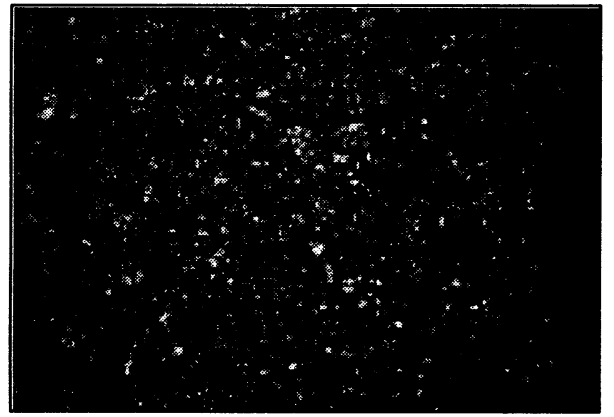

b) 混合後

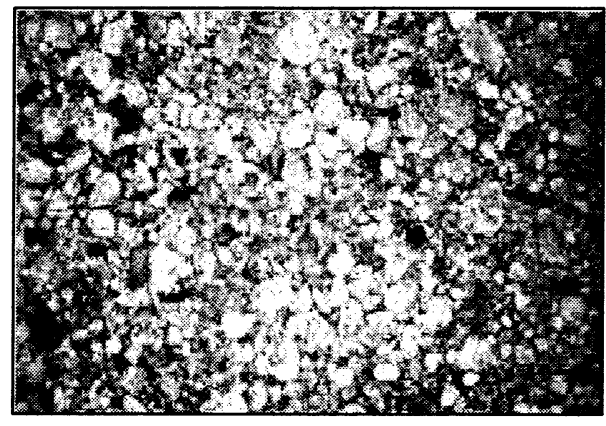

c) 反応後

図 - 5 供試体表面の変化（Mod. II As.・細骨材十石粉） 反応条件 : $375^{\circ} \mathrm{C} \cdot 35 \mathrm{MPa}$ ，反応時間： $180 \mathrm{sec}$

\section{6. 骨材回収能力に関する検討}

前項までの結果から, 極めて良好な抽出性能および試 験精度が認められた超臨界水反応試験について，アスフ アルト抽出試験としての害用化を検討する上では，骨材 回収能力, 中でも細骨材および石粉等, 微細骨材分に対 する分離・回収精度の評価が必要不可欠である.

本項では, 微細骨材分に対する抽出および骨材回収精 度を評価するため, 細骨材 (砕砂: 杤木県産硬質砂岩, 粒径 $0.075 \sim 2.36 \mathrm{~mm}$, 粗目砂: 茨城県産洗砂, 粒径 0.075 〜2.36 mm) および石粉（石灰岩微粉末: 秩父石灰社製夕 ンカル TB149, 粒系 $0.075 \mathrm{~mm}$ 以下）に, 前項同様の St.As. および Mod. II As.を加熱混合した 2 種類の供試体を用い て反応試験に実施した.

微細骨材供試体の作製・計量手順を以下に示す。
表 - 6 反応前後における通過質量百分率

\begin{tabular}{c|ccc}
\hline \multirow{2}{*}{$\begin{array}{c}\text { ふるいい目 } \\
\text { ふ呼び法 } \\
(\mathrm{mm})\end{array}$} & \multicolumn{3}{|c}{$\begin{array}{c}\text { 通過質量百分率 } \\
\text { (\%) }\end{array}$} \\
\cline { 2 - 4 } & 配合粒度 & St.As. & Mod. II As. \\
\hline 4.75 & 100.00 & 100.00 & 100.00 \\
2.36 & 100.00 & 100.00 & 100.00 \\
0.600 & 54.46 & 54.92 & 51.75 \\
0.300 & 34.04 & 34.47 & 33.64 \\
0.150 & 19.80 & 18.09 & 18.24 \\
0.075 & 11.92 & 10.59 & 10.62 \\
\hline
\end{tabular}

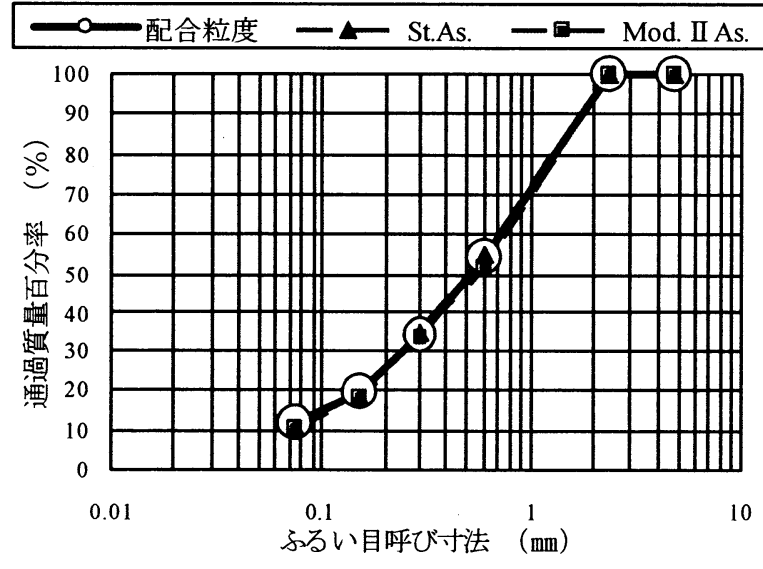

図 - 6 混合時の配合粒度と回収骨材の推定粒度

(1) 供試体作製時の誤差を軽減させるため, 砕秒，粗砂， 石粉を $2.36 ， 1.2 ， 0.6 ， 0.3 ， 0.075 \mathrm{~mm}$ に一分級し，各 骨材の粒度組成を整える.

(2) 試料総質量が $50 \mathrm{~g}$ となる上う，舗装設計斾工指針 ${ }^{11}$ に記載されている密粒度アスファルト混合物（最大 粒径 $13 \mathrm{~mm} ）$ の微細骨材分に相当する砕砂 $66.7 \%$, 粗 砂 $20.2 \%$ ，石粉 $13.1 \%$ の骨材配合比にて混合する.

(3) 微細骨材の混合試料を質量が一定となるまで炉乾燥 $\left(110^{\circ} \mathrm{C}\right)$ させた後, デシケータ内で室温まで放冷し, 被膜前質量 $\left(\mathrm{M}_{\mathrm{a}}\right)$ を $1.0 \times 10^{4} \mathrm{~g}$ まで計量する.

(4) 計量後の試料を電気炉にてアスファルト混合温度ま で加熱した後, 同温度のアスファルトを重量比で $6.0 \mathrm{wt} \%$ 添加し, 器具への付着や損失, 偏在等に注意し ながら, 均一に加熱混合する.

(5) 混合後の試料をデシケータ内で静置・放冷し，(2) と 同様に被膜後質量 $\left(\mathrm{M}_{\mathrm{f}}\right)$ を計量する，なお，(2)，(5) の質量差からアスファルト量を求め, $6.0 \pm 0.1 \mathrm{wt} \%$ (内

掛）となったものを 3 分割し，反応試験に供した.

反応条件は, 前項の検討から優れた抽出性能が確認さ

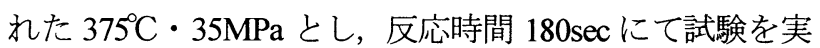


施した. なお, 推定 As.量の算出方法は前項と同様である.

図 - 5 は，上段からMod.IIAs.混合前，混合後，超臨界 水反応後に撮影した供試体表面の一例である.

微細骨材供試体についても，粗骨材供試体と同様に混 合したMod. II As.が 180 secの反応時間で十分に除去され, 反応後（図－5c）の試料からは皮膜前（図-5a）と遜 色なく白色の石粉分が視認された. また，推定As.量に関 しても，St.As.が+ 0.22\%，Mod. II As.が - 0.12\% と高精度 の結果が得られ，微細骨材に対する超臨界水の優れた抽 出性能が認められた.

反応後の回収骨材について, $2.36,0.6,0.3,0.15,0.075$ mmにてふるい分け（骨材洗い試験）を行い，骨材配合粒 度の推定を試みた. 反応前後における通過試料百分率を 表 - 6 に示す. また, 骨材回収能力を表すひとつの参考と して，供試体作製時の配合粒度と回収骨材より推定した 粒度曲線を図 - 6 に示した.

骨材配合粒度の推定誤差は，St.Asおよび Mod.II As. を混合した供試体ともに，2.36 mmでは確認されず， $0.3 \mathrm{~mm}$ において St.As.が+0.43\%，Mod.IIAs.が-0.40\%，0.075 mm では St.Asが-1.33\%，Mod.IIAs.が-1.30\% と，微細粒分の みを配合した供試体にも関わらず高精度の試験結果が得 られた. また，この結果から供試体作製時に使用した砕 砂 (砂岩), 粗砂 (洗砂), 石粉 (石灰岩微粉末) につい ては，高温・高圧水反応による骨材の溶解または破砕等 の構造的変化が，生じていないものと概ね認識される.

以上より，超臨界水はSt.AsおよびMod.II As.を混合し た微細骨材分に対しても，優れたアスファルト抽出性能 と骨材回収能力を有していると言える。

\section{7. まとめ}

本研究では，超臨界水を用いた抽出試験に関する基礎 検討として，アスファルトの抽出に要する反応時間と温 度・圧カレベルとともに，St.As.および Mod.II As.に対す る抽出性能と骨材回収能力を評価した.

以下に，本研究より得られた知見をとりまとめる.

（1）高温・高圧水反応によるアスファルト抽出は，一定 時間でその抽出作用が完了し，超臨界水反応では $60 \mathrm{sec}$ の反応で約 $100 \%$ As.抽出率が得られる.

（2）高温・高圧水の抽出性能は，特に超臨界水に顕著で あり，既往方法の課題とされる ${ }^{3)}$ Mod.II As.に対しても， St.As.と同様，十分な抽出性能を有している.

（3）粗骨材供試体中の As.量推定については，仕込水量 の少ない条件下（450 C ・ 30MPa）を除く超臨界水反応に より, St.Asが-0.03〜-0.13\%, Mod.II As.が-0.01〜-0.08\% と優れた推定精度が得られる.

（4）微細骨材供試体に対しても，超臨界水反応を行うこ とで, St.Asが+0.22\%, Mod.IIAs.が-0.12\% と高精度の As. 量推定が可能である.
（5）St.AsおよびMod.IIAs.を混合した微細骨材分に対し ても，超臨界水は優れた骨材回収能力を有しており，反 応後における回収微細骨材分のふるい分け結果から，高 精度の配合粒度推定が可能である.

以上の結果は，超臨界水を用いた抽出試験の適用性， およびその有為性を十分に示唆している.

\section{8. 今後の課題と展望}

以下に，今後の課題と展望を挙げる.

（1）微細粒分のより厳密な採取・測定方法の確立による 試験精度の更なる向上.

（2）多品種のバインダーや埔装発生材等を対象とした抽 出性能と骨材回収能力に関する検討.

（3）高温・高圧水反応が岩種, 鉣物種の異なる骨材また は軟石等に与える影響の究明.

（4）反応後に分離・回収されるアスファルト分および骨 材に関する具体的な性状評価.

（5）抽出試験としての実用化を視野とした，試験方法の 確立および試験装置の開発.

（6）装置の大型化と供試体の増量による実用的検討およ び既往方法との比較評価.

なお，本研究に使用した反応装置は，基礎検討用試作 装置であり, 内容積や仕込水量との関係から許容処理量 は，微細骨材供試体（アスファルト量 : 約 6.0\%) で $20 \mathrm{~g}$ 前後であった. 今後も, 人体や環境に対する安全性の向 上と, 簡便かつ経済的な抽出試験の実現に向けて, 引続 き積極的かつ具体的な検討を重ねる必要がある.

謝辞 : 本研究は, 学術フロンティア研究事業の一環とし て文部科学省の補助金をもって遂行されたものである. ここに記して，深甚なる感謝の意を表す.

\section{参考文献}

1）(社)日本道路協会 : 舖装設計施工指針, pp.263-273，2001.

2）(社)日本道路協会 : 舖装再生便覧，pp.205-215，0000.

3）(社)日本道路協会 : 舗装試験法便覧別冊, pp.174-189, 1996.

4）建設白書 : 各論，環境庁 (H4 年版)，pp.244

5）山之口浩, 荒井孝雄 : アスファルト抽出試験の新しい溶剂 の検討，道路建設，No.5/8，pp.63-68，1993.

6）白浜幸則，奥平真誠：塩素系溶剂を用いない抽出試験に関 する一検討，道路建設，No.6/1, pp.58-64, 1994.

7）武田昭, 加藤進, 渡辺孝志, 幡野彰一 : 炭化水素系溶剂を 用いた自動アスファルト抽出試験の検討，舗装，No.31-2， pp.19-24, 1996.

8）阿尻 雅文，環境適合型プロセスとしての超臨界水の利用, 資源環境対策, Vol.34, No.12, pp.24-30, 1998.

9）加納陽輔，秋葉正一，栗谷川裕造，河合糺茲 : 高温・高圧 水によるアスファルト混合物のバインダー除去，J. Jpn. Petrol. Inst, Vol.48, No.6, pp.358-359, 2005. 


\section{A STUDY ON TEST OF EXTRACTION OF ASPHALT FROM ASPHALT MIXTURE USING SUPERCRITICAL WATER}

\section{Yosuke KANO, Shoichi AKIBA, Yuzo KURIYAGAWA and Tadashi KAWAI}

\footnotetext{
Though the 1.1.1trichloroethane has been chiefly used in the test of extraction of asphalt so far, it was abolished in 1995 because of the consideration of safety to man and the environment. As a result, it is a current state that a substitute solvent of the vegetableor the oil is selected in each organization, and the full automation machine is developed. However, these methods still have some problems about the method of the extraction of the reforming asphalt, dryness, and the waste fluid processing.

Therefore, to solve these problems, we attempted the use of supercritical water to the extraction examination. As a result, it was elucidated that supercritical water had an enough ability to extract asphalt, and to collect a corpuscle material. This suggests being able to use water to test of extraction as a solvent, and we report on these.
} 